\title{
Combinational Drug Therapy Induced Severe Hyponatremia in a Hypertensive Patient- A Case Report
}

\author{
HB Kavya ${ }^{1, *}$, Mohammed Mustafa ${ }^{1}$, Ashamol KM², Hitha Kommeri², Reya Merin Biju² \\ Department of Pharmacy Practice, Sree Siddaganga College of Pharmacy B H Road, Tumkur, Karnataka, INDIA.
}

\begin{abstract}
Hyponatremia, ranging from mild to severe and from asymptomatic to symptomatic, is a serious medical condition that requires immediate medical management. The frequent factors that precipitate hyponatremia include decreased intake of sodium, inappropriate secretion of antidiuretic hormone, and concurrent use of medications that impair water excretion. Weakness, nausea, vomiting, perplexity, dizziness, physical inactiveness, seizure, and coma are some of the often symptoms presented with hyponatremia. Discontinuing the offending agent and providing additional support is vital in restoring the serum sodium level. In this case report, a 63-year-old male patient was presented to the hospital with symptoms of giddiness, tremors, and 3-4 episodes of convulsion. $\mathrm{He}$ has a past history of diabetes and hypertension and is on regular medication. Laboratory findings showed the presence of hyponatremia with a serum $\mathrm{Na}^{+}$value of $115 \mathrm{mmol} / \mathrm{l}$. On assessing this case, it is found that ARB/thiazide combination (telmisartan + chlorthalidone) has induced hyponatremia and is managed by treating with a hypertonic saline solution together with alteration of ARB/thiazide combination to calcium channel blocker. Gradually, the serum sodium level was normalized and the patient became stable.
\end{abstract}

Key words: Combinational drug therapy, Angiotensin receptor blockers, Thiazide diuretics, Hyponatremia, Hypertension.

\section{INTRODUCTION}

Hypertension is a major predisposing factor for the subsequent occurrence of cardiovascular disease and renal dysfunction. Besides, it is seen as the main co-morbidity among people with diabetes. According to Joint National Committee (JNC-8) guidelines, antihypertensive such as diuretics, angiotensin-converting enzyme inhibitors (ACE-I), angiotensin receptor blockers (ARBs), and calcium channel blockers (CCBs) are recommended as firstline treatment of hypertension. ${ }^{1}$ In elderly hypertensive patients, a combination therapy consisting of ARBs and thiazide diuretics is widely used.
Hyponatremia is a major electrolyte disorder where the sodium concentration $\left(\mathrm{Na}^{+}\right)$in plasma is $<135 \mathrm{mmol} / 1$ (135-145mmol/1). This condition leads to mortality in severe cases and also imparts financial burden on patients. ${ }^{2}$ Decreased intake of sodium, improper secretion of antidiuretic hormone, and treatment of hypertension with ARBs and diuretics constitute the key factors responsible for hyponatremia. The common symptoms correlated with low blood sodium levels are weakness, nausea, vomiting, confusion, giddiness, lethargy, seizure, and coma. ${ }^{3}$ The therapeutic approach for hyponatremia involves withdrawal of the offending drug, fluid restriction ( $<1 \mathrm{~L} /$ day), and infusion of either normal saline
DOI: 10.5530/ijopp.14.4.63

Address for correspondence: Dr. Kavya HB,

Assistant Professor,

Sree Siddaganga College of Pharmacy, BH Road, Tumkur-572102, Karnataka, INDIA.

Phone no: +91 8748909687 Email id: kavyapharma158@ gmail.com

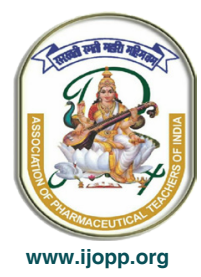


if symptoms are mild or hypertonic saline $(3 \% \mathrm{NaCl})$ if symptoms are severe. ${ }^{4}$

This case report discloses an incident of ARB/thiazide drug-induced severe hyponatremia and discusses the course of action taken for the improvement of hyponatremia.

\section{CASE REPORT}

A 63-year-old male, diabetic, and hypertensive for the last 25 years was hospitalized due to giddiness and tremors for 20 days with 3-4 episodes of convulsion on the day of admission. He had been on combination treatment consisting of $40 \mathrm{mg}$ of telmisartan and $12.5 \mathrm{mg}$ of chlorthalidone once daily for hypertension for the past 5-6 years and was also taking metformin $500 \mathrm{mg}$ once daily for diabetes.

\section{On admission, the patient's vital functions were}

BP: $120 / 80 \mathrm{mmHg}$

PR: 90bpm

RR: 22bpm

Temperature: $98.5^{\circ} \mathrm{F}$

\section{Systemic examination}

CNS: Post-ictal status with tongue bite present

CVS: S1S2+

RS: B/L NVBS+

P/A: soft and non-tender

\section{Laboratory investigations include}

$\mathrm{Hb}: 13.6 \mathrm{~g} / \mathrm{dl}(14-18 \mathrm{~g} / \mathrm{dl})$

RBC: 4.66million cells/cumm (4.7-6.1million cells/ cumm)

WBC: 11,200cells/cumm (4,000-11,000 cells/cumm)

Platelets: 2.31lakhcells/cumm (1.5-4.5 lakh/cumm)

$\mathrm{Na}^{+}: 115 \mathrm{mmo} / 1(135-145 \mathrm{mmol} / \mathrm{l})$

$\mathrm{K}^{+}: 3.5 \mathrm{mmol} / 1(3.5-5.5 \mathrm{mmol} / \mathrm{l})$

Serum Creatinine: $0.5 \mathrm{mgdl}(0.6-1.2 \mathrm{mg} / \mathrm{dl})$
Blood urea: $11 \mathrm{mg} / \mathrm{dl}(7-20 \mathrm{mg} / \mathrm{dl})$

Total bilirubin: $1.1 \mathrm{mg} / \mathrm{dl}(0.3-1.2 \mathrm{mg} / \mathrm{dl})$

Direct bilirubin: $0.4 \mathrm{mg} / \mathrm{dl}(0.0-0.2 \mathrm{mg} / \mathrm{dl})$

Urine sodium: $215 \mathrm{mmol} / 1(40-220 \mathrm{mmol} / 1)$

The laboratory findings showed the presence of hyponatremia with a serum $\mathrm{Na}^{+}$value of $115 \mathrm{mmol} / 1$. Further, the high urine sodium level of $215 \mathrm{mmol} / 1$ also indicates sodium loss through urine. These reports confirmed the diagnosis of drug-induced hyponatremia and thus discontinued the combination treatment. Moreover, no other drugs that can cause hyponatremia were administered by the patient. Hyponatremia was corrected with intravenous infusion of $3 \% \mathrm{NaCl}$ along with the alteration of the anti-hypertensive drug to amlodipine $5 \mathrm{mg}$ once daily. On the following day, the serum sodium level improved to $120 \mathrm{mmol} / 1$; then on the next day, it was further increased to $126 \mathrm{mmol} / 1$ and continued the hypertonic saline solution. On the fourth day, the plasma sodium level recovered to $130 \mathrm{mmol} / 1$ at which point $3 \% \mathrm{NaCl}$ infusion was discontinued. On the fifth day, the sodium electrolyte $\left(\mathrm{Na}^{+}\right)$concentration in serum significantly improved to $134 \mathrm{mmol} / 1$, and the patient was discharged.

\section{DISCUSSION}

A low dose of a thiazide diuretic in combination with ARB is a favorable antihypertensive medication with fewer incidences of causing electrolyte imbalance. However, this case represents an example of ARB/ thiazide combination induced critical hyponatremia in a hypertensive patient. Mild hyponatremia, where serum $\mathrm{Na}^{+}$concentration between 125 to $132 \mathrm{mmol} / \mathrm{l}$, is usually asymptomatic though manifested with moderate symptoms such as drowsiness or vomiting. More severe hyponatremia observed in patients with serum $\mathrm{Na}^{+}$ $<120 \mathrm{mmol} / 1$ require hospitalization and may either exhibit no symptoms or show manifestations such as vomiting, nausea, fragility, dizziness, confusion, seizure, and even coma. ${ }^{4}$ Similar cases of severe hyponatremia which occurred following treatment with the ARB/ thiazide combination were reported in aged hypertensive patients in Korea ${ }^{5}$ and Japan. ${ }^{6}$

Advanced age, women, poor body mass index, and simultaneous use of other medications that impair water excretion (eg: NSAIDs, SSRIs, SNRIs, benzodiazepines, ACE-I, ARBs) are the risk factors of thiazide induced hyponatremia. ${ }^{7}$ Although hyponatremia is generally 
observed within the initial few weeks of treatment, it can also be observed after years of treatment particularly when contributory factors are present, such as agerelated impairment in renal function, administration of drugs that affect free-water clearance, or variations in sodium or water intake. Thiazide diuretics reduce free water clearance by the kidneys, which in turn, prompt thiazide-induced hyponatremia. Moreover, they interfere with the dilution of urine by hindering sodium chloride cotransport in the distal tubule. Thereby, the elimination of $\mathrm{Na}^{+}$is increased while the excretion of free water is diminished. ${ }^{4}$ Moreover, AT1 receptor inhibition induced by $A R B s$ decreases renal tubular sodium reabsorption and aldosterone secretion which further advances disease severity. ${ }^{8}$

Withdrawal of the offending drug, water restriction, proper diet, and administration of either isotonic or hypertonic saline constitutes the treatment for hyponatremia. Hypertonic saline is preferred as firstline therapy in patients displaying acute manifestations such as seizure or coma to ensure the rapid onset of response. ${ }^{4} \mathrm{An}$ increase of serum sodium by $4-6 \mathrm{mEq} / 1$ within the first $6 \mathrm{hrs}$ should be the target of treatment for symptoms to subside. However, the increase in serum sodium should not exceed $8 \mathrm{mEq} / 1$ during the first $24 \mathrm{hr}$ because more rapid correction increases the chance of developing a disorder called the osmotic demyelination syndrome (ODS) which can even be fatal. A calcium channel blocker or beta-blocker is preferred for patients who need an alternative antihypertensive treatment. ${ }^{9}$ Furthermore, continuous monitoring of serum sodium levels is essential for preventing and reducing the likelihood of hyponatremia.

\section{CONCLUSION}

Though ARB/thiazide combinations are approved as effective antihypertensive agents, this case presents an incidence of ARB/Thiazide-induced severe hyponatremia in an elderly male patient. Hence, rapid replenishment of serum sodium levels and alteration of the current antihypertensive regimen is advised. Moreover, adequate monitoring for serum sodium concentration together with patient education regarding fluid consumption and salt intake is recommended.

\section{ACKNOWLEDGEMENT}

We are extremely thankful to all our beloved teachers of Sree Siddaganga College of Pharmacy, Tumkur for their encouragement, support, and guidance.

\section{CONFLICT OF INTEREST}

The authors declare no conflict of interest.

\section{ABBREVIATIONS}

JNC: Joint National Committee; ACE-I: AngiotensinConverting Enzyme Inhibitors; ARB: Angiotensin Receptor Blockers; CCB: Calcium Channel Blockers; NSAIDs: Non-Steroidal Anti-Inflammatory Drugs; SSRIs: Selective Serotonin Reuptake Inhibitor; SNRIs: Serotonin-Norepinephrine Reuptake Inhibitor; ODS: Osmotic demyelination syndrome.

\section{REFERENCES}

1. James PA, Oparil S, Carter BL, Cushman WC, Dennison-Himmelfarb C, Handler J, et al. 2014 Evidence-based guideline for the management of high blood pressure in adults: report from the panel members appointed to the Eighth Joint National Committee (JNC 8). JAMA. 2014;311(5):507-20. doi: 10.1001/jama.2013.284427, PMID 24352797.

2. Zilberberg MD, Exuzides A, Spalding J, Foreman A, Jones AG, Colby C, et al. Epidemiology, clinical and economic outcomes of admission hyponatremia among hospitalized patients. Curr Med Res Opin. 2008;24(6):1601-8. doi: 10.1185/03007990802081675, PMID 18426691.

3. Hwang KS, Kim GH. Thiazide-induced hyponatremia. Electrolyte Blood Press. 2010;8(1):51-7. doi: 10.5049/EBP.2010.8.1.51, PMID 21468197.

4. Mann SJ. The silent epidemic of thiazide-induced hyponatremia. J Clin Hypertens (Greenwich). 2008;10(6):477-84. doi: 10.1111/j.1751-7176.2008.08126.x, PMID 18550938.

5. Kim DR, Cho JH, Jang WS, Kim JS, Jeong KH, Lee TW, et al. Severe hyponatremia associated with the use of angiotensin II receptor blocker/ thiazide combinations. Electrolyte Blood Press. 2013;11(2):56-9. doi: 10.5049/ EBP.2013.11.2.56, PMID 24627706.

6. Yamada H, Asano T, Aoki A, Ikoma A, Yoshida M, Kusaka I, et al. Combination therapy of angiotensin II receptor blocker and thiazide produces severe hyponatremia in elderly hypertensive subjects. Intern Med. 2014;53(7):749-52. doi: 10.2169/internalmedicine.53.1738, PMID 24694490.

7. Chow KM, Szeto CC, Wong TY, Leung CB, Li PK. Risk factors for thiazideinduced hyponatraemia. Q J Med. 2003;96(12):911-7. doi: 10.1093/qjmed/ hcg157, PMID 14631057.

8. Goldberg MR, Bradstreet TE, McWilliams EJ, Tanaka WK, Lipert S, Bjornsson TD, et al. Biochemical effects of losartan, a nonpeptide angiotensin II receptor antagonist, on the renin-angiotensin-aldosterone system in hypertensive patients. Hypertension. 1995;25(1):37-46. doi: 10.1161/01.hyp.25.1.37, PMID 7843751.

9. Liamis G, Filippatos TD, Elisaf MS. Thiazide-associated hyponatremia in the elderly: what the clinician needs to know. J Geriatr Cardiol. 2016;13(2):175-82. doi: 10.11909/j.issn.1671-5411.2016.02.001, PMID 27168745. 